\title{
State Answers to Religious Diversity in Germany and Singapore: History, Philosophy and Strategy
}

\author{
Kevin YL Tan* and Matthias Roßbach**
}

(Received 05 September 2019; accepted 06 September 2019)

\begin{abstract}
This Article focuses on the extent to which the different legal approaches of Germany and Singapore to religious diversity were shaped by history. It first analyzes the development in Germany and describes four phases of the development of the law on the relationship between church and state. Starting with the consequences of reformation, it shows that - for centuries - the relationship between denominations had been the crucial matter of this body of law. Only later, the law dealt with conflicts between religion and atheism. This Article then presents the fundamental rights approach of the Basic Law and examines it against the backdrop of the historical development and recent challenges. Second, this Article offers a historical account of Singapore's attempts at regulating and managing religious diversity. It starts with the establishment of a British trading post on the island in 1819 and runs up to the present day. As a result of mass migration in its early years, Singapore was to become, in the twentieth century, one of the most religiously and culturally diverse nations in the world. This Article shows that Singapore has sought to regulate and manage the various religious groups through a combination of legislation and state policy.
\end{abstract}

Keywords: Religious freedom; religion; constitution; Germany; Singapore; state approaches to religion

\section{A. Introduction}

This Article examines state answers to religious diversity by Germany and Singapore and the extent to which their different approaches were shaped by these countries' respective pasts. The rationale for such a comparison is not obvious. Germany is a large, European state with a population of almost 83 million, occupying a land area of over 357,000 square kilometers, while the tiny city state of Singapore has only 5.6 million people, squeezed into some 721 square kilometers. And while Singapore has been religiously diverse since it became a British colony in 1824, Germany has for centuries only experienced religious diversity within Christianity.

The complexion of Germany, however, is fast changing. In 1950, around 95\% of its people were Christians, whether Protestants or Catholics. ${ }^{1}$ That number has dropped to 55\% in 2017. In the meantime, the number of persons who are non-religious, or do not subscribe to any particular faith, rose to around $37 \%$ of the population. ${ }^{2}$ This massive increase was the result of German reunification in 1989, which saw huge numbers of erstwhile atheist Germans reintegrated into

\footnotetext{
${ }^{*}$ Adjunct Professor, Faculty of Law, National University of Singapore.

${ }^{* *}$ Head of "Coordination of Federal and European Policy and International Affairs", State Chancellery of North RhineWestphalia, Berlin Office; Postdoctoral Adjunct Researcher, Humboldt University Berlin, Faculty of Law.

${ }^{1}$ Fachserie A, Bevölkerung und Kultur: Volksound Berufszählung vom 6. Juni 1961, Heft 5, Bevölkerung nach der Religionszugehörigkeit, STATistisches Bundesamt, Stuttgart 21 (1966).

${ }^{2}$ Religionszugehörigkeiten in Deutschland 2017, Forschungsgruppe WeltanschauUngen IN Deutschland (2018), https://fowid.de/meldung/religionszugehoerigkeiten-deutschland-2017.
} 
the reunited Germany. And in recent years, Germany's Muslim population rose to more than 4.5 million, or $5.5 \%$ of its total population, largely as a result of immigration from Turkey, but also immigration from Syria and other parts of the war-torn Middle East. ${ }^{3}$

Germany has long taken a relatively liberal approach to the management of religious diversity, especially after the end of World War II. Liberal states like Germany typically adopt a position of religious tolerance and neutrality. They maintain a healthy distance between themselves and religious forces and refrain from advancing a vision of the common good in the common space against religious communities.

In recent times, religious diversity has become a highly debated issue in German politics, especially with the arrival of refugees since 2015 . What legal answers do we have to deal with an increasing diversity of religions in Germany? Although the German law on the relationship between state and religion dates back more than five centuries, ${ }^{4}$ this Article argues that the law of the pre-constitutional past alone does not prepare Germany for solving the challenges ahead.

In contrast the Singapore state-which is one of the most ethnically, culturally, and religiously diverse states in the world-adopts an interventionist approach in securing religious and racial harmony. The religious harmony now evident to any visitor did not come into being by happenstance, but through the state's active involvement in regulating and managing this diversity.

This Article is largely historical and is organized in three parts. The first part describes the phases of development in the German law governing religious diversity, while the second part looks at developments and management frameworks in the Singapore. The Article concludes with an analysis of the contrasting strategies adopted by Germany and Singapore.

\section{B. Phases of the Modern Law on Religious Diversity in Germany ${ }^{5}$ \\ I. First Phase: Denominational Diversity}

The first phase of modern German law governing the relationship between church and state ${ }^{6}$ can be said to have begun in 1517 when Martin Luther put forward his Ninety-Five Theses and started the Reformation. ${ }^{7}$ Up to this time, Catholicism was the only established religion in the German states, and indeed, throughout the Holy Roman Empire (the Heiliges Römisches Reich or simply, "the Reich"). This body of law dealt primarily with the division within the church, ${ }^{8}$ and signaled the beginning of religious diversity in a very unique sense: Diversity of denominations. ${ }^{9}$ It is a myth that the state was religiously neutral after the Reformation. ${ }^{10}$ In this regard, there were rather remarkable differences between the Reich and the territories. After the Peace of Augsburg in 1555, the territories were governed by the principle of "cuius regio, eius religio"-literally "whose realm,

\footnotetext{
${ }^{3}$ See Anja Stichs, Wie viele Muslime leben in Deutschland? (Bundesamt für Migration und Flüchtlinge, Working Paper 71, 2016). According to estimates of this paper, between 4.4 and 4.7 million Muslims lived in Germany on December $31,2015$.

${ }^{4}$ See generally Christian Waldhoff, Die Zukunft des Staatskirchenrechts, in DIE VerFASSUNGSORDNUNG FÜr RELIGION UND Kirche In Anfechtung Und BewÄhrung: 42 Essener Gespräche Zum Thema StaAt Und Kirche 59 et seq. (Burkhard Kämper \& Hans-Werner Thönnes eds., 2008); Hans Michael Heinig, ÖfFentlich-Rechtliche ReligiOnsGesellschaften 74 (Duncker \& Humblot 2003).

${ }^{5}$ These phases are taken from Waldhoff, supra note 4.

${ }^{6}$ ERnst-WolfGang Böckenförde, Recht, StaAt, Freiheit 92 et seq. (1991); Harold J Berman, LAW ANd REVOlution: The Formation of the Western Legal Tradition (1983).

${ }^{7}$ Heinrich de Wall \& Stefan MuCKel, KirChenrecht 23 et seq. (5th ed. 2017); Martin Heckel, Zur Entwicklung des deutschen Staatskirchenrechts von der Reformation bis zur Schwelle der Weimarer Verfassung, in 2 GESAMMELTE SCHRIFTEN: StaAt, Kirche, Recht, Geschichte 366 (Klaus Schlaich ed., 1989).

${ }^{8}$ HeINIG, supra note 4, at 74 et seq.

${ }^{9}$ Stefan Korioth, Die Entwicklung des Staatskirchenrechts in Deutschland seit der Reformation, in STAATSKIRCHENRECHT Oder Religionsverfassungsrecht? 39 et seq. (Hans Michael Heinig \& Christian Walter eds., 2007).

${ }^{10}$ Horst Dreier, Kanonistik und Konfessionalisierung-Marksteine auf dem Weg zum Staat, 57 JURISTENZeITUNG 1 (2002).
} 
his religion"11_ under which the sovereign could determine his subjects' religion. ${ }^{12}$ There was thus no diversity within the territories. Rather, it was a condominium of the spiritual and the political sphere and thus no separation between church and state. On the Catholic side, ecclesiastical principalities existed right up until $1803 .{ }^{13}$ The principle of religious neutrality could only be found at the level of the old Reich-and even there, only within certain limits. ${ }^{14}$ Neutrality simply meant the maintenance of parity between the two confessions.

\section{Second Phase: Beyond Denominational Diversity ${ }^{15}$}

This state of affairs changed at the end of the eighteenth and the beginning of the nineteenth centuries, which signaled the beginning of the second phase of development of this body of law. This phase was characterized by three interrelated factors. First, the Enlightenment of the late seventeenth and early eighteenth centuries had put the individual at the center of statechurch-individual relationships. ${ }^{16}$ In this new schema, individuals were presumed to have their own views on religion. Indeed, an individual could also choose to be non-religious. Second, the end of the Holy Roman Empire in 1806 also meant an end of ecclesiastical states. ${ }^{17}$ Third, the nineteenth century also marked the beginning of pluralism of denominations within a single state. ${ }^{18}$ The German Federation of 1815, and later the German Empire of 1871, were essentially federations with a high degree of autonomy in cultural and religious matters and left the regulation of religious matters to their individual states. ${ }^{19}$

In 1794, the General Laws for the Prussian State contained the "freedom of religion" for the individual. ${ }^{20}$ But it also provided that churches specifically acknowledged by the state had the privileged status of a public corporation. These principles are still in force today. The Prussian practice, however, diverged from legal theory. The law enhanced the special connection between throne and altar, a distinct feature of the Prussian state, and thus favored Protestantism, the de facto official religion. ${ }^{21}$ The Prussian state thus contributed to a de facto discrimination of Catholics within state and in social life. ${ }^{22}$

\section{Third Phase: Religious Diversity Under the Weimar Constitution}

The connection between throne and altar ended with the November Revolution of $1918 .^{23}$ The beginning of Weimar democracy ushered in a new epoch of the development of the law on religious diversity. It dealt not only with the relationship of the different Christian denominations, but

\footnotetext{
${ }^{11}$ See Dietmar Willoweit, Deutsche Verfassungsgeschichte 167 et seq. (5th ed. 2005); Axel Gotthard, Der Augsburger ReLIGIONSFRIEDEN (2004).

${ }^{12}$ Dreier, supra note.

${ }^{13}$ Waldhoff, supra note 4 , at 61 .

${ }^{14}$ Waldhoff, supra note 4 , at 61 .

${ }^{15}$ See generally Heiner de Wall \& Andreas Gestrich, Constitutional Complexity and Confessional Diversity, in POLITICAL and Legal Perspectives: The Dynamics of Religious Reform in Northern Europe 1780-1920 149 (Keith Robbins ed., 2010).

${ }^{16}$ Jörg-Detlef Kühne, Die Reichsverfassung Der Paulskirche, 470 et seq. (2nd ed. 1998); Bernd Jeand’Heur \& Stefan Korioth, GrundzÜge Des StaAtskirchenrechts 39 et seq. (2000).

${ }^{17}$ Peter Unruh, Religionsverfassungsrecht 37 (2015); Jeand'Heur \& Korioth, supra note 16, at 38; Waldhoff, supra note 4 , at 60 et seq.

${ }^{18}$ Alexander Freiherr von Campenhausen, StaAtskirchenrecht 33 (3rd ed. 1996).

${ }^{19}$ See de Wall \& Gestrich, supra note 15 , at 149.

${ }^{20}$ Korioth, supra note 9 , at 44 et seq.

${ }^{21}$ Waldhoff, supra note 4 , at 62 .

${ }^{22}$ See, e.g., Christoph Link, Kirchliche Rechtsgeschichte 147 et seq. (3rd ed. 2017); Reinhold Zippelius, Staat und Kirche 158 et seq. (2nd ed. 2009).

${ }^{23}$ Waldhoff, supra note 4, at 62; Martin Heckel, Kontinuität und Wandlung des deutschen Staatskirchenrechts unter den Herausforderungen der Moderne, 44 ZEITSCHRIFT FÜr EvANGELISCHES KIRCHENRECHT 347 (1999).
} 
also contemplated the possibility of the non-religious individual. ${ }^{24}$ This development resulted from anti-religious protests and the rise of non-religious forces within the Weimar Republic. ${ }^{25}$ Laws on religious freedom now went beyond managing denominational conflicts. The Weimar Constitution thus codified the principles that had dominated the law on the relationship between church and state for more than a century.

Article 135 of the Constitution guaranteed to individuals "full religious freedom and freedom of conscience." ${ }^{26}$ This freedom, however, lacked teeth because corollary rights—such as the right to form associations or express opinions - could be restricted by "general laws." 27 This did not, however, render the constitutional protection of religious freedom meaningless vis-àvis the Reichstag. One predominant view among Weimar legal scholars was that the legislature was prohibited from enacting laws targeting a specific religion. ${ }^{28}$ However, the wording was not clear and was thus the subject of a scholarly debate. ${ }^{29}$ The atrocities of the National Socialists demonstrated how vulnerable the guarantee of religious freedom was under the Weimar Constitution.

Article 137 provided that there be "no state church" 30 and gave every religious community autonomy. ${ }^{31}$ The constitution, however, also reaffirmed the status of religious communities as public-as opposed to private-corporations. ${ }^{32}$ Unlike in France at that time, there was no hostile, insurmountable separation of state and church, but a "friendly separation" 33 and a "cultural compromise." 34

\section{Fourth Phase}

The German Basic Law, which came into force in 1949, adopted the institutional provisions of the Weimar Constitution. ${ }^{35}$ It did so in a unique manner: Article 140 of the Basic Law incorporates the relevant articles of the Weimar Constitution ${ }^{36}$ —Articles 136-139 and 141-seriatim. In so doing, the drafters of the Basic Law avoided further discussion on a highly delicate issue ${ }^{37}$ and continued the tradition started by the General Laws of the Prussian State of $1794 .^{38}$

However, one fundamental difference distinguishes the Basic Law's provisions on religious diversity from those of its predecessors: Freedom of religion is now provided for upfront under Article 4 of the Basic Law, which states:

\footnotetext{
${ }^{24}$ Waldhoff, supra note 4, at 63, n. 28.

${ }^{25}$ See Gerhard Anschütz, Art. 135 WRV, in Die Verfassung Des Deutschen Reichs Vom 11 August 1919 para. 4 , n. 2 (1933).

${ }^{26}$ Gerhard Anschütz, Die Religionsfreiheit, in 2 HANDBUCH Des DeUTSCHEN STAATSREChTs 675, 681 (Gerhard Anschütz \& Richard Thoma eds., 1932).

${ }^{27}$ Waldhoff, supra note 4, at 63.

${ }^{28}$ Horst Dreier, Grundrechtsrepublik Weimar, in DAS WAGNIS DER Demokratie 175, 189 (Horst Dreier \& Christian Waldhoff eds., 2018).

${ }^{29} I d$. at 189.

${ }^{30}$ HeInIG, supra note 4, at 176. See also Stefan Magen, Art 140 GG, in BundeSVERFASSUNGSGERICHTSGESETZ para. 54 (Dieter C. Umbach et al. eds., 2005).

${ }^{31}$ HeINIG, supra note 4 , at 91 et seq.

${ }^{32}$ Weimar CONST. art. 137 (Ger.).

${ }^{33}$ JeAnd'Heur \& Korioth, supra note 16, at 42; Fritz Stier-Somlo, Politik, 73 (6th ed. 1926).

${ }^{34}$ Christoph Gusy, Die Weimarer Reichsverfassung 321 et seq. (1997).

${ }^{35}$ See generally Peter Badura, Das Staatskirchenrecht als Gegenstand des Verfassungsrechts, in HANDBUCH DES StaAtskirchenrechts Der Bundesrepublik Deutschland 211, 236 et seq. (Joseph Listl \& Dietrich Pirson eds., 1994); Klaus Stern, Das StaAtsrecht Der Bundesrepublik Deutschland Band IV/2 1201 et seq. (2011).

${ }^{36}$ Article 140 of the Weimar Constitution provides: "The provisions of Articles 136, 137, 138, 139 and 141 of the German Constitution of 11 August 1919 shall be an integral part of this Basic Law."

${ }^{37}$ Martin Hollerbach, Die Kirchen unter dem Grundgesetz, 26 VeröfFentlichungen Der Vereinigung Der DeUTSCHEN STAATSRECHTSLEHRER 57, 59 (1968); VON CAMPENHAUSEN, supra note, at 49.

${ }^{38}$ Korioth, supra note 9 , at 40 .
} 
Article 4 [Freedom of faith and conscience]

(1) Freedom of faith and of conscience and freedom to profess a religious or philosophical creed shall be inviolable.

(2) The undisturbed practice of religion shall be guaranteed.

(3) No person shall be compelled against his conscience to render military service involving the use of arms. Details shall be regulated by a federal law.

As can be seen, its wording does not allow for any restrictions on the right ${ }^{39}$ and thus affords the freedom of religion even higher protection than to the freedom of speech in Article 5. But much more important than the wording is the fact that freedom of religion is now undoubtedly part of a fundamental rights catalogue with teeth under Article 1 of the Constitution. Article 1(3) states that the "basic rights"-including rights under Article 4-"shall bind the legislature, the executive and the judiciary as directly applicable law."

Thus, the Basic Law adopts an individual rights approach to the protection of religious freedom. ${ }^{40}$ This approach was, in part, a reaction against the atrocities of the Nazi regime. ${ }^{41}$ Under the Basic Law, individual rights serve as a bulwark against dictatorship and authoritarianism ${ }^{42}$ and protect individuals against an ideology that ranks the whole above the individual. The Basic Law acknowledges the individual as part of society, but in cases of doubt, the individual may not be merely an object of the will of the whole. ${ }^{43}$ This is the principal essence of human dignity, a paramount principle of the Basic Law.

The primacy of the human dignity principle elevates individual rights beyond normal politics. ${ }^{44}$ They are legally binding and enforceable against the majority and against other imperatives, such as the unity of the state. And as the freedom of religion is regarded as touching upon the core of an individual's identity, the Basic Law accords this fundamental right a particularly high degree of protection. It may only be restricted to protect other constitutional values of the same rank, and even then, restrictions must be proportionate. ${ }^{45}$ Thus, it may be argued that the fundamental rights of others might be a ground for restricting one's religious freedom, provided the restriction accords with the principle of proportionality and does not touch upon the core of an individual's identity and thus his or her human dignity. ${ }^{46}$

\section{Religious Diversity in Germany: The Emerging Paradigm}

Even in the early decades of the Basic Law, religious diversity remained that of denominations of Christianity. In 1950, $95.8 \%$ of the West German population belonged to one of the two Christian

\footnotetext{
${ }^{39}$ Roman Herzog, Art. 4 GG, in Maunz/Dürig, GG paras. 3 et seq. (2018).

${ }^{40}$ Horst Dreier, Gilt Das Grundgesetz Ewig? 24 et seq. (Carl Friedrich von Siemens Stiftung ed., 2009). For a comparison of the extent of the enforcement of individual rights against the legislature between the Weimar Constitution and the Basic Law, see Horst Dreier, Grundrechtsrepublik Weimar, in DAS Wagnis Der Demokratie 175, 186 et seq. (Horst Dreier \& Christian Waldhoff eds., 2018).

${ }^{41}$ Hermann von Mangoldt, 5 Parlamentarischer Rat 63, 71 (Eberhard von Pikart \& Wolfram Werner eds., 2010); Peter Badura, Generalprävention und Menschenwürde, 19 Juristenzeitung 337, 341 (1964); Hasso Hofmann, Die ENTdECKUNG Der MensChenrechte 11 (1999).

${ }^{42} \mathrm{See}$ Bundesverfassungsgericht [BVerfG] [Federal Constitutional Court], Nov. 4, 2009, ENTSCHEIDUNGEN DES BundESVERFASSUNGSGERICHTS [BVerfGE] 300, 327 et seq.

${ }^{43}$ Matthias Herdegen, Art 1 I GG, in MAUnz/DÜRIG, GG para. 36 (2018).

${ }^{44}$ Horst Dreier, Art 1 I GG, in DreiER, GG para. 42 (2013); Wolfram Höfling, Art. 1 I GG, in SACHS, GG para. 51 (2017).

${ }^{45}$ Konrad Hesse, GrundzÜge Des Verfassungsrechts para. 312 (20th ed. 1999); Dieter Grimm, Multikulturalität und Grundrechte, in Das Recht Des Menschen In Der Welt 135, art. 144 et seq. (Rainer Wahl \& Joachim Wieland eds., 2003).

${ }^{46}$ See Hesse, supra note 45 , at para. 317 et seq.
} 
churches. ${ }^{47}$ The first fundamental shift took place when the territory of the former German Democratic Republic ("GDR" or "East Germany") became part of the Federal Republic of Germany in 1990 with the Reunification. In the GDR, only $40 \%$ of the population had belonged to one of the Christian churches. ${ }^{48}$

The effects of the reunification, migration, and the loss of members by Christian churches signaled a fundamental change in religious dynamics compared to the early days of the Basic Law. Indeed, in 2017, only around 55\% of the German population belonged to either the Protestant or Catholic churches, $37 \%$ percent had no religion, and around $5 \%$ of the population were Muslims. ${ }^{49}$

The homogeneity of the society of the 1950s had been replaced by a variety of religious pluralism: That of religious and non-religious parts of the population. Consequently, the most important constitutional cases on religious diversity do not stem from conflicts between two different religions, but rather between religion and atheism. This can be exemplified by one of the most important cases of the Federal Constitutional Court.

In 1995, the State of Bavaria had a regulation ${ }^{50}$ that provided for the installation of crosses in school classrooms. This rule was challenged by non-religious pupils - or rather by their parentsand struck down by the Federal Constitutional Court. ${ }^{51}$ In doing so, the court did not refer to objective values such as the peaceful coexistence of religious and non-religious members of the society or the institutional neutrality of the state in religious matters. Instead, it applied religious freedom negatively ${ }^{52}$ by holding that crosses in classrooms violated the religious freedom of the pupils because the pupils are confronted with religious expressions against their will. ${ }^{53}$ This is not to suggest that everyone has a right to be spared from any religious expressions. Individuals have no right to be protected from others who wear crosses or religious dress, ${ }^{54}$ or from ringing church bells. The reasons are twofold: First, in most cases, the individual has the possibility of escaping this influence; and second, the religious expressions of others are themselves protected by freedom of religion. However, the mandated cross in the classroom is a different case because the pupil has no legal way to evade or "escape" the cross as there is a duty to attend school. ${ }^{55}$ As such, the court concluded that the pupils were forced to study under the influence of a religious symbol. ${ }^{56}$

This holding was highly controversial. ${ }^{57}$ In particular, the interpretation of the cross as a purely religious symbol has been under attack from several sides. Some argue that it is not merely the symbol of Christianity, but rather a symbol of the culture and the history of the occident and therefore not necessarily a religious symbol. ${ }^{58}$ Others question whether the court has a right to interpret and determine the meaning of the cross at all.

\footnotetext{
${ }^{47}$ Entwicklung der Religionszugehörigkeiten nach Bundesländern, 1950-2011, FORSCHUNGSGRUPPE WELTANSCHAUUNGEN IN DeUTSCHLAND (July 8, 2014), https://fowid.de/meldung/entwicklung-religionszugehoerigkeiten-nach-bundeslaendern-19502011.

${ }^{48}$ See Detlef Pollack, Von der Volkskirche zur Minderheitskirche, Zur Entwicklung von Religiosität und Kirchlichkeit in der DDR, in SOZIALgesCHICHTE DER DDR 271 (Hartmut Kaelble et al. eds., 1994).

${ }^{49}$ Religionszugehörigkeiten in Deutschland 2017, ForschungSGrupPe WeltanschauUngen IN Deutschland (Oct. 8, 2018), https://fowid.de/meldung/religionszugehoerigkeiten-deutschland-2017.

${ }^{50}$ The wording of the "Bayerische Volksschulordnung" (Bavarian school regulations) in Section 13, paragraph 1 BayVSO at that time was as follows: "The school supports the parents with the religious education of the children. School prayer, school worship service and school devotion are possibilities of this support. In each classroom a cross is to be attached. Teachers and pupils are obliged to respect the religious feelings of all."

${ }^{51}$ Bundesverfassungsgericht [BVerfG] [Federal Constitutional Court], May 16, 1995, 93 ENTSCHEIDUNGEN DES BUNDESVERFASSUNGSGERICHTS [BVerfGE], 1 et seq.

${ }^{52} I d$. at 15 et seq.

${ }^{53}$ See Christian Waldhoff, Kreuz als Rechtsproblem, 2 KIRCHE UND RECHT 153, 158 et seq. (2011).

${ }^{54}$ Bundesverfassungsgericht, BVerfGE 93, at 21.

${ }^{55}$ See Stefan Huster, Die Ethische Neutralität Des Staates 129 et seq. (2002).

${ }^{56}$ Bundesverfassungsgericht, BVerfGE 93, at 18.

${ }^{57}$ See Dieter Grimm, Ich Bin Ein Freund Der Verfassung 145 et seq. (Oliver Lepsius et al. eds, 2017).

${ }^{58}$ But see Bundesverfassungsgericht, BVerfGE 93, at 19. See also Waldhoff, supra note 4, at 160 et seq.
} 
Irrespective of these differences, it is crucial to note that the issue is debated in the language of individual rights. The conflict between religion and atheism is not solved by institutional approaches, but by interpreting individual rights and by carefully balancing them against each other-by applying the principle of proportionality.

This also happens in even more difficult cases in which state employees are involved. In a recent case, a teacher's religious freedom to wear religious symbols in class was pitted against her pupils' right not to be confronted with religious symbols during lessons. ${ }^{59}$ This case entailed a balance between the positive and negative religious freedom of two individuals. The court concluded that, as a general rule, the teacher's positive religious freedom prevailed, since the wearing of a religious symbol was not deemed to be an expression of the state but of the teacher as an individual. ${ }^{60}$ The court further held that the wearing of such a symbol may be ameliorated by the wearing of other symbols by other teachers, and this would contribute to an open and pluralistic society. ${ }^{61}$ It was only where the wearing of such a symbol disturbs school peace in a concrete way that restrictions may be placed on teachers wearing religious symbols in class. ${ }^{62}$

The Federal Constitutional Court made it clear that an abstract concept like "school peace" could not be used to restrict an individual's religious freedom unless the risk was real and significant. Even so, it was an argument of last resort. Where possible, other ways to resolve the conflictlike transferring the teacher to another school ${ }^{63}$ —have to be used before prohibiting the wearing of religious symbols by teachers. ${ }^{64}$ This reasoning reflects Germany's approach to religious diversity in which individual liberty, and not concepts like "religious harmony," is the dominant paradigm.

\section{The Development of Religious Freedoms in Singapore}

In contrast to Germany's long but fairly uncomplicated historical interactions with faith, the case of Singapore is much briefer but more complex. For a start, Singapore has a largely immigrant population and was populated relatively recently. The small native Malay-Muslim population was quickly outnumbered by the Chinese immigrants and has, since 1836, been in the minority. While large numbers of migrants came from neighboring countries with similar social, cultural, religious, and linguistic similarities with its native population, even larger numbers came from much farther afield-China and India in particular. As we shall see, this resulted in a much more complex and diverse population than Germany. The British-who ruled Singapore as a colony for 140 years-had to grapple with this diversity, and this led to the deployment of a totally different strategy for the management of religious freedoms on the island.

\section{Singapore's Ethno-Religious Demography}

Prior to the arrival of British settlers in January 1819, Singapore was part of the Johor-Riau-Lingga Empire. When the British first arrived, Singapore was sparsely inhabited. Estimates range between

\footnotetext{
${ }^{59}$ Bundesverfassungsgericht [BVerfG] [Federal Constitutional Court], Jan. 27, 2015, 138 ENTSCHEIDUNGEN DES BundesVERFASSUNGSGERICHTS [BVerfGE], 296. See generally Diana Zacharias, Schutz vor religiösen Symbolen durch Art 4 GG? Ein Beitrag zu den negativen religiösen Freiheitsrechten, in KIRCHE UND RELIGION IM SOZIALEN RECHTSSTAAT 987 (2003).

${ }^{60} 1 \mathrm{BvR} 471 / 10$, supra note 59 , at 328 et seq.

${ }^{61} 1 \mathrm{BvR} 471 / 10$, supra note 59 , at 339 et seq.

${ }^{62} 1 \mathrm{BvR} 471 / 10$, supra note 59 , at 334 et seq.

${ }^{63} 1$ BvR 471/10, supra note 59, at 341.

${ }^{64}$ ERnST-WOLFGANG BÖCKENFÖRDE, DAS GRUNDRECHT DER GEWISSENSFrEIHEIT 61 et seq. (1970); Niklas Luhmann, Die Gewissensfreiheit und das Gewissen, 90 ARCHIV Des ÖFFENTLICHEN ReCHTS 257, 274 et seq. (1965).
} 
150 persons to just under 1,000. Most of the population were Malays and were followers of Temenggong Abdul Rahman, whose settlement centered around the mouth of the Singapore River. What was clear was that the population rose rapidly within the next few months. By the middle of 1819, it was estimated that the population had reached several thousand due to massive immigration from the region, and mainly from China. ${ }^{65}$ As Saw explains:

The news about the establishment of the free port of Singapore in the centre of an area rich in trade soon spread far and wide, and traders and settlers from places outside Peninsular Malaysia began to flock to the island. The news soon reached the southern parts of China and Chinese traders, who had previously travelled to such places as Malacca, Brunei and Manila, found it safer and more profitable to visit Singapore instead ....

At about the same time, news of the British trading centre in Singapore reached the Indian sub-continent, and Indian traders soon came to the island in fairly large numbers. Apart from traders, there were indentured labourers and convicts among the steady stream of Indians coming into the country in the first few years ....

A third major group were the Indonesian immigrants who came from the neighbouring islands in the East Indies in the south. Among them were the Javanese, Bugis and Balinese who were shrewd traders and merchants. Being persons of the same racial stock, these newcomers intermingled with the Malays and became assimilated through marriage and other affiliations. ${ }^{66}$

Sir Thomas Braddell, writing in 1861, estimated that there were 5,874 persons on the island, of which 1,150 were Chinese and 4,724 were Malays. ${ }^{67}$ When the first census was taken in in January 1824 , Singapore's total population stood at $10,683 .{ }^{68}$ Growth in the population varied across the various ethnic groups, with the Chinese recording the highest annual rates of growth over almost a century, between 1824 and 1921, except for a brief period between 1860 and 1871. ${ }^{69}$ By 1849, the Chinese became the majority ethnic group in Singapore. The following table shows the distribution of population by race (by percentage) between 1824 and $2006:^{70}$

As can be seen from the table above, the distribution between the three main ethnic communities in Singapore has remained relatively stable since 1911, with the Chinese making up almost three-quarters of the population and the Malays being the most significant majority group. This is despite the fact that Singapore's current population stands at approximately 5.6 million. Ethnic diversity has thus long been one of the hallmarks or characteristics of Singapore society.

Diversity exists not only at the ethnic level but also in terms of religions. In 2015, the distribution of persons professing the major faiths in Singapore is as follows:

\footnotetext{
${ }^{65}$ Saw Swee Hock, The Population of Singapore 6 (Institute of Southeast Asian Studies 3rd ed. 2012) [hereinafter "SAW"].

${ }^{67}$ Thomas Braddell, Statistics of British Possessions in the Straits of Malacca (Pinang Gazette Printing Office 1861).

${ }^{68}$ Saw Swee Hock, Population Trends in Singapore, 1819-1967, 10 J. SE. AsIAN Hist. 36, 38 (1969).

${ }^{69} \mathrm{SAW}$, supra note 65 , at 12.

${ }^{70}$ SAW, supra note 65 , at 29.
} 


\begin{tabular}{|c|c|c|c|c|}
\hline Year & Chinese & Malays & Indians & Others \\
\hline 1824 & 31.0 & 60.2 & 7.1 & 1.7 \\
\hline 1830 & 39.4 & 45.9 & 11.15 & 3.2 \\
\hline 1836 & 45.9 & 41.9 & 9.9 & 2.6 \\
\hline 1849 & 52.9 & 32.2 & 11.9 & 3.0 \\
\hline 1871 & 56.8 & 27.1 & 11.9 & 4.0 \\
\hline 1891 & 67.1 & 19.7 & 8.8 & 4.3 \\
\hline 1911 & 72.4 & 13.8 & 9.2 & 4.7 \\
\hline 1931 & 75.1 & 11.7 & 9.1 & 4.2 \\
\hline 1947 & 77.8 & 12.1 & 7.4 & 2.8 \\
\hline 1967 & 74.4 & 14.5 & 8.1 & 3.0 \\
\hline 1957 & 75.4 & 13.6 & 9.0 & 2.0 \\
\hline 1970 & 76.2 & 15.0 & 7.0 & 1.8 \\
\hline 1980 & 76.9 & 14.6 & 6.4 & 2.1 \\
\hline 1990 & 74.7 & 13.5 & 7.6 & 4.2 \\
\hline 2000 & 76.7 & 13.9 & 7.9 & 1.4 \\
\hline 2010 & 74.1 & 13.4 & 9.2 & 3.3 \\
\hline
\end{tabular}

\begin{tabular}{|c|c|}
\hline Religion & Distribution \\
\hline Buddhism/Taoism & $43.2 \%$ \\
\hline Christianity & $18.8 \%$ \\
\hline Islam & $14.7 \%$ \\
\hline Hinduism & $5.0 \%$ \\
\hline No Religion & $18.5 \%$ \\
\hline
\end{tabular}

\begin{tabular}{|c|c|c|c|c|c|}
\hline & Buddhist & Taoist & Muslim & Hindu & Christian \\
\hline Chinese & $43.2 \%$ & $12.9 \%$ & & & $20.9 \%$ \\
\hline Malay & & & $99 \%$ & & \\
\hline Indian & & & $21.3 \%$ & $60.0 \%$ & \\
\hline
\end{tabular}

In ethnic terms, the distribution of religious adherents across the ethnic groups is as follows: Quite clearly, almost all Malays are Muslims, and hardly any Malays nor Chinese are Hindus. Furthermore, the majority of Hindus are also Indians. The reinforced cleavages of ethnicity and religion make for a potentially volatile mix and lowers the likelihood of moderation and toleration. As the political scientist Martin Seymour Lipset observed: 
A stable democracy requires relatively moderate tension among its contending political forces. And political moderation is facilitated by the system's capacity to resolve key dividing issues before new ones arise. If the issues of religion, citizenship, and "collective bargaining" are allowed to accumulate, they reinforce each other, and the more reinforced and correlated the sources of cleavage, the less likelihood for political tolerance. ${ }^{71}$

It is against this democratic backdrop that developments in the state management of religious diversity in Singapore need to be understood.

\section{The Period of Laissez Faire Tolerance}

From 1819, when the British established a trading station in Singapore, until 1824, when the island was seceded to the British by Sultan Hussain, the sovereignty of Singapore was disputed. As such, the British had no jurisdiction to legislate for the island, nor make provisions for the conduct of judicial business, nor operate a police force. The only legal basis for the conduct of government was in the Treaty of Friendship and Alliance which Thomas Stamford Raffles concluded with Sultan Hussein on February 6, 1819, which affords considerable recognition of "native law" whatever it may be. Article VII of the Treaty provides generally that:

The mode of administering justice to the native population shall be subject to future discussion and arrangement between the contracting parties, as this will necessarily, in a great measure, depend on the laws and usages of the various tribes who may be expected to settle in the vicinity of the English factory. ${ }^{72}$

Specifically, the Treaty made special arrangements and exceptions for the application of the English law to the Malay inhabitants of the island as follows:

In all cases regarding the ceremonies of religion, and marriages, and the rules of inheritance, the laws and customs of Malays will be respected, where they shall not be contrary to reason, justice or humanity. In all other cases, the laws of the British authority will be enforced with due consideration to the usages and habits of the people. ${ }^{73}$

At this point, the British were primarily concerned with securing a trading post in Singapore and ensuring that the Sultan was comfortable and that his subjects would be protected. Precedent for this kind of legal intervention had long been established in British India, where the British, among other things, codified and "Anglicized" Islamic or "Mohammedan" and "Hindoo" Laws.

In the arrangements Raffles made for the administration of Government in Singapore in June 1819, he mandated that at 10 A.M. every Monday morning, the Sultan, the Tumungong, and the Resident shall meet at the Court House or Council House (Rumah Bicara) to preside over a session whereby every:

Captain, or head of a caste, and all Penghulus of campongs and villages, shall attend ... and make a report or statement of such occurrences as may have taken place in the Settlement, and represent any grievance or complaint that they may have to bring before the Council for its consideration . . . ${ }^{74}$

\footnotetext{
${ }^{71}$ Martin Seymour Lipset, Political Man: The Social Bases for Politics 89 (Doubleday 1960).

${ }^{72}$ Treaty of Friendship and Alliance art. 7, Feb. 6, 1819, reprinted in Roland ST. JoHn BradDell, The Law OF THE STRAITs SetTlements: A Commentary 146 (Kelly \& Walsh 1915).

${ }^{73}$ Memorandum by Sir Stamford Raffles, cl. 6 (1823), reprinted in Roland ST. JOHn BRAdDELl, The LAW OF THE STRAITS Settlements: A Commentary 152 (Kelly \& Walsh 1915).

${ }^{74}$ Arrangements Made for the Government of Singapore arts. 4-5, June 1819, reprinted in ROLAND ST. JOHN BRADDELL, The Law of the Straits Settlements: A Commentary 149 (Kelly \& Walsh 1915).
} 
Disputes occurring within the various communities were to be dealt with by community leadersthe Capitan Cina for the Chinese and the Temengoong for the Malays - and the British intervened only when trouble occurred between the different ethnic groups.

It was only in 1826 that the Straits Settlements - comprising Penang, Malacca, and Singaporewas granted a Charter of Justice. This important document-Letters Patent Establishing the Court of Judicature for the Prince of Wales' Island, Malacca and Singapore ${ }^{75}$ - not only established the Court of Judicature presided over by a Recorder, but also brought into force the entirety of English law in the Settlements. The Charter provides that the Court shall administer English justice "so far as the several Religions, Manners, and Customs of the Inhabitants of the said Settlement and Places will admit."76 In the administration of criminal law, the Court shall:

... administer criminal Justice in such or the like Manner and Form, or as nearly as the Condition and Circumstances of the Place and the Persons will admit of, as our Courts of Oyer and Terminer and Gaol Delivery, or may, in that Part of our United Kingdom called England, due Attention being had to the several Religious, Manners, and Usages of the native Inhabitants. ${ }^{77}$

The Court was further empowered to

... frame such Rules and Regulations for the due Administration of Justice in and by the said Court or Courts, respectively, and to regulate every Matter incident thereto, as they shall see fit, conforming, as nearly as may be, to the Rules generally practised for the Administration of Justice in the several Courts of request and Courts for Recovery of small Debts, within that Part of our United Kingdom called England, so as that the Administration of Justice in and by the said Court or Courts may, as far as Circumstances will permit, always be adapted to the Religions, Manners, and Customs of the several Classes and Tribes of Inhabitants, from Time to Time, within the said Settlement and Places afore said. ${ }^{78}$

Finally, the court was authorized to appoint constables and "subordinate Peace Officers" to assist in the administration of justice in such manner "as nearly as the different Religions, Customs, and Manners of the different Inhabitants of the said Settlement and Places shall require or will admit."79

As will be observed, the phrase "so far as the Religions, Customs and Manners ... will admit"80 appears several times in the Second Charter, demonstrating a general reluctance on the part of the British to uncompromisingly impose English on the Settlements. It evinces a sensitivity to the feelings of the local population-at least insofar as private laws are concerned. English criminal law — which was based on the common law_-was applied with a light touch and with the understanding the accommodation be given for the application of native law as well.

\footnotetext{
${ }^{75}$ Letters Patent Establishing the Court of Judicature at Prince of Wales' Island, Singapore and Malacca in THE EAST INDIEs (Mission Press, 1827).

${ }^{76} I d$.

${ }^{77} I d$.

${ }^{78} I d$.

${ }^{79} I d$.

${ }^{80}$ See generally M.B. Hooker, English Law in Sumatra, Java, the Straits Settlements, Malay States, Sarawak, North Borneo and Brunei, in Laws of South East Asia, Vol II: European Laws In South-East Asia 299 (M.B. Hooker ed., 1988).
} 


\section{Criminalizing Blasphemy}

Blasphemy is a common law offence, ${ }^{81}$ having its origins in ecclesiastical law. ${ }^{82}$ As such, it would have been part of the law of the Straits Settlements from the time of the Second Charter in 1826 right up till the introduction of the Penal Code in 1870, where a modified version of blasphemy was statutorily prescribed. There are, however, no records or reports of any prosecutions for blasphemy, nor indeed for any kind of criminal libel between 1826 and 1870. The English Criminal Libel Act $1819^{83}$ would also have applied to the Straits Settlements. Section 1 of this Act empowered the court to seize copies of any "blasphemous libel" or any "seditious libel tending to ... excite his Majesty's subjects to attempt the alteration of any matter in Church or State as by law established, otherwise than by lawful means." Again, there is no report of this legislation having been enforced in the Straits Settlements.

The common law of blasphemy as enforced in England was specifically codified by Macaulay in the Indian Penal Code of 1860. The Penal Code was adopted and passed into law by the Straits Settlements Legislative Council in 1871 and came into effect in 1872. These provisions now manifest themselves in Part XV of the Penal Code of Singapore. This part consists of five sections, the first four of which were in Macaulay's original version as enacted. The last provision, Section 298A, was inserted into the Penal Code in 2017. Section 295 makes it an offence for anyone to destroy, damage, or defile any place or worship or any sacred object "with the intention of thereby insulting the religion of any class of persons" knowing that that class of persons would consider such an act to be an insult to their religion." Any person who "voluntarily causes disturbance to any assembly lawfully engaged in the performance or religious worship or religious ceremonies," 84 or who with intention to wound the feelings of any person or insulting his religion, trespasses any place or "any place of sepulchre or any place set apart for the performance of funeral rites," or "offers any indignity to any human corpse, or causes disturbance to any persons assembled for the performance of funeral ceremonies" $"$ would also be guilty of an offence. Section 298 makes it an offense for anyone to deliberately wound "the religious or racial feelings of any person" by word, gesture, exhibition or deed. The new Section 298A further provides that any person who "knowingly promotes or attempts to promote, on grounds of religion or race, disharmony or feelings of enmity, hatred or ill-will between different religious or racial groups" or who "commits any act which he knows is prejudicial to the maintenance of harmony between different religious or racial groups and which disturbs or is likely to disturb public tranquillity is guilty of an offence."

\section{Regulating "Native" Personal Law: Crisis and Response}

Despite the fact that a number of public order issues arose that gave rise to potential inter-religious and inter-ethnic conflict, the colonial authorities did not intervene legislatively. Many of the disputes between the various ethnic and religious groups were dealt with from a public order and peace perspective, rather than as religious conflicts. Thus, from the 1820 s onwards, the colonial authorities openly assigned building sites for religious buildings of the different faiths close to each other. One such example is in South Bridge Road, where a mosque, a Hindu Temple, and a Chinese temple sit cheek-by-jowl with each other. From the 1840 s onwards, the police began regulating religious processions and ceremonies as these proved noisy and irritated the European population.

\footnotetext{
${ }^{81}$ See Courtney Kenny, The Evolution of the Law of Blasphemy, 1 CAMBridge L. J. 127 (1922).

${ }^{82}$ See Rex v. Taylor, 1 Vent. 293 (1676).

${ }^{83}$ Criminal Libel Act 1819,3 \& 4 Geo. c. 12.

${ }^{84}$ Singapore Penal CODE $\$ 296$.

${ }^{85}$ Singapore PenAl CODE $\$ 297$.
} 
It might be argued that Britain's initial reluctance to interfere in the "native affairs" changed significantly after it became more heavily involved in the governance of the Malay states. Under the Treaty of Pangkor of 1874, Raja Abdullah of Perak agreed to accept the appointment of a British Resident to "advice" him on good government of the state in exchange for British protection and the ouster of Sultan Ismail from the throne. Similar arrangements were made by the Sultans of Negeri Sembilan and Selangor that same year, and then by the Sultan of Pahang in 1888. These states federated in 1895 to form the Federated Malay States, a protectorate of the British Crown. The significance of this development in the Malay peninsula lay in the special status of the Sultan as not only head of state, but also protector of Islam.

The first legislative intervention came in 1880 with the enactment of the Mohamedan Marriage Ordinance. Interestingly, this legislation was prompted by the Muslims themselves and was not a top-down initiative on the part of the British. In 1875, 143 Arab memorialists petitioned the British Government to intervene to formalize procedures for Muslim marriages and their recognition. A problem for highly-mobile Arab traders was the non-recognition of their marriages to local women-it was argued that the local kathis were "ineffective" and Arab traders urged the British to appoint official kathis. In 1880, the Legislative Council passed the Mohamedan Marriage Ordinance, ${ }^{86}$ but this was not implemented till December 1, 1882. Another piece of legislation that dealt specifically with religious organizations was the 1905 Mohammedan and Hindu Endowments Ordinance ${ }^{87}$ which provided a regulatory framework for the management of the various Muslim and Hindu trusts, temples, and mosques.

Subsequent interventions were, however, prompted by international and local developments which fractured the local community. The Sepoy Mutiny of February $1915,{ }^{88}$ orchestrated by members of the Ghadr Party in India, made the British realize the need to better manage religious passions. The mutiny was staged by the Indian Muslim 5th Light Infantry, then stationed in Singapore. Already afflicted by low morale and slack discipline, the troops were influenced by a local Gujarati Muslim coffee-shop owner, Kassim Mansoor, who sowed the seeds of enmity against the British. When their tour of duty ended, the troops were slated to leave for Hong Kong, but Mansoor and others spread wild rumors that they were going to be sent to Turkey instead to fight against their "Muslim brothers." The mutiny lasted ten days and resulted in the death of 44 British officers, soldiers, and civilians, 56 sepoys, 3 Chinese, and 2 Malay civilians. After a Court of Inquiry that lasted over two months, 47 mutineers were publicly executed outside Outram Prison, and another 167 mutineers were sentenced to transportation or imprisonment. Kassim Mansoor was found guilty of treason and hanged.

Almost as a direct response to the Mutiny, the Straits Government created the Mohammedan Advisory Board on June 19, 1915. Speaking at the inauguration of the Board, Colonial Secretary R.J. Wilkinson explained the rationale for its creation:

The Board will be a voice or tongue to all the Mohammedans in Singapore, for voicing matters connected with Mohammedan religion or custom. If there is anybody who has a desire they can communicate their wishes to this Board and it will be communicated to the Government by the Board. If there is anything which may be an obstacle to the Moslem people, that matter will be considered by this Board, in order to inform the Government.... If the Board gives any advice to the Government it will not be made light of. ${ }^{89}$

Interestingly, Wilkinson stated that the Board's establishment was a ground-up initiative led by prominent community leader Syed Mohamed bin Agil who had "been all round the world and ...

\footnotetext{
${ }^{86}$ Straits Settlements, Mahomedan Marriage Ordinance V of 1880 (Sing.).

${ }^{87}$ Straits Settlements, Mohammedan and Hindu Endowments Ordinance XVII of 1905 (Sing.).

${ }^{88}$ See R.W.E. Harper \& Harry Miller, Singapore Mutiny (1984).

${ }^{89}$ Moslem Advisory Board, Malaya Tribune, June 21, 1915, at 8.
} 
seen a lot of things concerning the administration of different countries." 90 The Board was renamed the Muslim Advisory Board in $1947^{91}$ even though there were objections from the Islamic community on the use of the term "Mohammedan" from as early as $1933 .{ }^{92}$

In 1951, a Muslim government lawyer, Ahmad Ibrahim-later to become independent Singapore's first Attorney-General-proposed the establishment of a Shariah Court to deal properly with matters involving Muslim marriage and divorce. ${ }^{93}$ A special committee in the Muslim Advisory Council was set up to discuss this proposal, and in July 1952, it was announced that an Islamic court would be established. ${ }^{94}$ This was effected by a new Muslims Ordinance-which would replace the Mohammedan Marriage Ordinance-which was introduced in the Legislative Assembly in November 1955. It was finally enacted in April 1957. The New Ordinance established a Shariah Court with jurisdiction over all Muslim matrimonial matters. Litigants could appeal Shariah Court decisions to a Shariah Appeal Board.

Shortly after the Muslim Advisory Board was reconstituted in 1947, a group of Muslim leaders established a committee to consider the formation of a "central Muslim body for Singapore, or of strengthening any existing organization to become the mouthpiece of Singapore Muslims." 95 Nothing appears to have been done to supplant the Muslim Advisory Board until 1960, when the Board got together with the All-Malaya Muslim Missionary Society, the Singapore Religious Teachers' Association, and the Mohammediah Movement under the Chairmanship of Ahmad Ibrahim, Singapore's State Advocate-General, to discuss the formation of a "liaison committee to strengthen and unite all sections of the Muslim community." 96 Nothing much appeared to have come out of this until the end of the 1950s, when the Government once again looked to tweak the legislation concerning Muslims in Singapore. A new Administration of Muslim Law Bill was introduced in the Legislative Assembly in 1960. After the second reading of the Bill, nothing was done till August 1966, when it was tabled for a third reading, after Singapore had become independent from the Federation of Malaysia. In addition to strengthening the Shariah Court, it constituted a central body, the Maglis Ugama Islam Singapura (MUIS) or Islamic Religious Council of Singapore, to replace the Muslim Advisory Board. The Administration of Muslim Law Act (AMLA) came into operation in 1968.

\section{Constitutionalizing Religious Freedom}

From 1824, when Singapore was ceded to the British, till independence in 1963, it operated under a colonial framework. The various constitutions that were promulgated through Letters Patent from the Crown contained no guarantees of civil or political liberties. It was only during the Constitutional Talks of 1956-1958 that there was a discussion on the need to secure the interests of the racial and religious minorities in Singapore. The Preamble to the 1958 Order in Council states that:

[I]t shall be the responsibility of the Government of Singapore constantly to care for the interests of racial and religious minorities in Singapore, and in particular that it shall be the deliberate and conscious policy of the Government of Singapore at all times to recognise

\footnotetext{
${ }^{90} I d$.

${ }^{91}$ Muslim Advisory Board Meets, STRAits Times, Oct. 5, 1947, at 3.

${ }^{92}$ Mohammedan or Muslim? What is the Correct Name?, Malaya Tribune, Mar. 25, 1933, at 18. See also "Muslim" Not "Mohammedan," STRAits Times, Nov. 25, 1946, at 3.

${ }^{93}$ Blythe at Muslim Party, STRAits Times, Dec. 29, 1951, at 7.

${ }^{94}$ Muslim Law Court Plan for the Colony, Straits Times, Jan. 14, 1952, at 7; Muslim Court Plan, SingaPORE FreE Press, July 14, 1952, at 5 .

${ }^{95}$ Muslims Form Committee, Singapore Free Press, Jan. 26, 1948, at 5; Central Body for Muslims, Straits Times, Feb. 24, 1948 , at 8 .

${ }^{96}$ Four Muslim Groups Get Together, STRAITs Times, Oct. 17, 1960, at 5.
} 
the special position of the Malays, who are the indigenous people of the Island and are in most need of assistance, and accordingly, that it shall be the responsibility of the Government of Singapore to protect, safeguard, support, foster and promote their political, educational, religious, economic, social and cultural interests and the Malay language. ${ }^{97}$

In 1963, when Singapore became part of the Federation of Malaysia, the Federal Constitution applied automatically to Singapore as it did to all constituent states. Article 3(1) of the Federal Constitution proclaims Islam as "the religion of the Federation," but quickly adds that "other religions may be practiced in peace and harmony." Article 11(1) gives every person "the right to profess and practise his religion and ... to propagate it" provided he does not "act contrary to any general law relating to public order, public health or morality." Article 11 goes on further to guarantee every religious group the right to: (a) manage its own religious affairs; (b) establish and maintain institutions for religious or charitable purposes; and (c) acquire and own property and to hold and administer it. In 1965, when Singapore seceded from the Federation, it imported Article 11 almost word-for-word as Article 15 of the Constitution. The Constitution does not forbid the state from engaging in activities related to religion.

Singapore's Parliament also appointed a Constitutional Commission under the chairmanship of Chief Justice Wee Chong Jin to consider, among other things, "how the rights of the racial, linguistic and religious minorities can be adequately safeguarded in the Constitution." 98 The Commission recommended the establishment of a separate body - the Council of State-to ensure that no legislation discriminated against "members of any racial, linguistic or religious group." 99 Parliament accepted this recommendation, and in 1969 created the Presidential Council whose role was to advise the Government on matters involving racial or linguistic minorities referred to it ${ }^{100}$ and to draw Parliament's attention to any Bill or subsidiary legislation that was discriminatory. ${ }^{101}$ In 1973, the Presidential Council was renamed the Presidential Council for Minority Rights.

\section{The Maintenance of the Religious Harmony Act-A Prophylactic Approach}

A final major intervention on the part of the Singapore Government came in 1990 with the introduction of the Maintenance of Religious Harmony Act ("MRHA"). This Act was a response to certain trends observed by Singapore's Internal Security Department ("ISD") as detailed in a 1989 White Paper entitled Maintenance of Religious Harmony presented to Parliament on December 26, 1989. The Government highlighted three key concerns: (a) an increase in the religious fervor and assertiveness among religious groups as part of a worldwide religious revival, thus leading to an increase in inter-religious tensions; (b) intra-religious confrontations and tensions; and (c) incidents of religious groups and leaders entering the realm of politics. ${ }^{102}$

The Act empowers the Minister for Home Affairs to issue restraining orders against any official or members of any religious group or institution to stop them from orally addressing any congregation or worshippers, or printing, publishing, editing, or distributing any publication, or from holding office in any editorial board or committee publication on several grounds. Restraining orders may be issued if the Minister "is satisfied" that the person concerned has or is attempting to: (a) cause feelings of enmity, hatred, ill-will or hostility between different religious groups; (b) carry out activities to promote a political cause, or a cause of any political party while, or under the guise of, propagating or practising any religious belief; (c) carry out subversive activities under the

\footnotetext{
${ }^{97}$ Sing. CONST. Preamble.

${ }^{98}$ See Report of the Constitutional Commission (Singapore Government Printers 1966).

${ }^{99} \mathrm{Id}$. at para. 46.

${ }^{100}$ SING. CONST. art. 76.

${ }^{101} \mathrm{Id}$. at art. 77.

${ }^{102}$ Maintenance of Religious Harmony, Cmd 21 of 1989 (Singapore: Singapore National Printers, 1989).
} 
guise of propagating or practising any religious belief; or (d) excite disaffection against the President or the Government while, or under the guise of, propagating or practising any religious belief. ${ }^{103}$ The Act also established a Presidential Council for Religious Harmony whose function is to consider and report to the Minister on matters affecting the maintenance of religious harmony in Singapore referred to it by the Minister or by Parliament, and to consider and make recommendations on orders referred to it by the Minister. All restraining orders must, within thirty days of their issue, be referred to the Council, which will make its recommendation to the President of Singapore who will either confirm or cancel the order. ${ }^{104}$ The Act was passed on November 9, 1990 and came into force on March 31, 1992.

\section{Conclusion}

History has shown that Singapore's interventionist approach was born out of political expediency. Religion was not a subject the state sought to regulate as such. To start with, the British authorities took a laissez-faire and openly tolerant approach to religious diversity and only began to react when public order problems broke out. Even so, the mode of regulation was conciliatory and inclusive and involved the establishment of boards or committees in which religious interests were represented, and which opposing views could be ventilated and taken into account by the Government. No religion was privileged, and the British did not attempt to impose their Christian faith on the population as such. Indeed, concessions were given to existing native law, custom, and practices. In particular, Muslims were given special treatment, largely because it was the predominant religion of the Malays - the "indigenous people" of Singapore - and partly because the practice of this faith required serious modifications of the prevailing personal law.

In the post-independence period, the Singapore state treated religion simply as another field of human activity. As an immigrant society with a broad inter-faith diversity, its approach is practical and unashamedly intrusive. It does not purport to tell its people what to believe in but will dictate what can and cannot be done in the public space. No religion is banned although a number of them have been blacklisted as cults with unhealthy social practices. Most significantly, Singapore has concerned itself with the second and third order effects of religious practice and treated them as public order and public security issues. The operating dictum appears to be "believe in whatever you want, and do whatever you want to do, but don't break the law." Such an approach is anything but liberal. It is statist and places state interests above those of the individual. In a strange way, such an approach has the tacit Hobbesian approval of its people who are wary of how explosive religious feelings and sentiments can be.

In contrast, the answer to Germany's challenges takes the form of a liberal, individual rights approach, which is the distinct feature of the Basic Law. Since the German Constitution has human dignity as its guiding principle, individual self-determination must first and foremost be ensured. ${ }^{105}$ Therefore, the paramount value is not premised on an abstract, objective aim of ensuring peaceful coexistence among the diverse religions per se, but to achieve this peaceful coexistence or "religious harmony" through the skillful balancing of individual rights. Human dignity requires that an individual's core identity ${ }^{106}$ —or religious belief — should not be subjugated to a

\footnotetext{
${ }^{103}$ Maintenance of Religious Harmony Act, Chapter 167A, $\$ 8$ (Sing.).

${ }^{104} I d$. at $\$ \$ 11-12$.

${ }^{105}$ GRUNDGESETZ [Basic Law] art. 1, para. 1 ("Human dignity shall be inviolable. To respect and protect it shall be the duty of all state authority.”); Bundesverfassungsgericht [BVerfG] [Federal Constitutional Court], Aug. 17, 1956, ENTSCHEIDUNGEN DES BUNDESVERFASSUNGSGERICHTS [BVerfGE] 85, 204 ("In liberal democracy, human dignity is the highest value.").

${ }^{106}$ Bundesverfassungsgericht [BVerfG] [Federal Constitutional Court] Dec. 20, 1960, ENTSCHEIDUNGEN DES Bundesverfassungsgerichts [BVerfGE] 45, 53; Bundesverfassungsgericht [BVerfG] [Federal Constitutional Court] Oct. 19, 1971, ENTSCHEIdungen des BundesverfassungsGerichts [BVerfGE] 98, 106; Bundesverfassungsgericht [BVerfG] [Federal Constitutional Court] April 11, 1972, ENTSCHEIdUngen DES BundesverfassungsGerichts [BVerfGE] $23,28$.
} 
mere state objective. ${ }^{107}$ Such a law may produce "religious harmony" as a convenient consequence, but it does not privilege "religious harmony" as an absolute value, nor achieve "religious harmony" at the cost of an individual's religious identity. This is to be contrasted against the wide remit that Singapore offers the executive in the case of the Maintenance of Religious Harmony Act. ${ }^{108}$

The challenges caused by religious diversity in Germany are not solved by empowering the state to issue orders against individuals or groups whose acts cause feelings of hostility between religious groups. One German law-Section 166 of the German Criminal Code-comes close to this. It provides:

Whosoever publicly or through dissemination of written materials defames the religion or ideology of others in a manner that is capable of disturbing the public peace, shall be liable to imprisonment not exceeding three years or a fine.

The German Federal Constitutional Court has, however interpreted this law by balancing the individual's freedom of speech against another's freedom of religion. ${ }^{109}$ "Public peace" is only violated if the speech causes certain persons to fear that they cannot live in a society without being discriminated against. ${ }^{110}$ Section 166 is thus interpreted narrowly and in the light of an individual rights approach: Sharp criticism of another religion does not alone satisfy the Code's requirements, but such speech must be "particularly rude and violating expression of disregard."111 German courts thus resolve conflicts through the application of proportionality ${ }^{112}$ analysis to ensure that the religious freedoms of contesting individuals are minimally infringed. ${ }^{113}$

As shown above, the Federal Constitutional Court made it clear that an abstract concept like "school peace" or "religious harmony" could not be used to restrict an individual's religious freedom unless the risk was real and significant. In the aforementioned case, ${ }^{114}$ other means to solve a conflict have to be used before prohibiting the individual right of a teacher to wear religious symbols. ${ }^{115}$ This reasoning reflects Germany's approach to religious diversity. After the atrocities of an authoritarian dictatorship, human dignity and individual self-determination were embedded in the Basic Law as paramount values. And given the crucial place of religion in an individual's identity, such individual rights - particularly the freedom of speech and the freedom of religionprevail over abstract considerations of peace or harmony in a society.

\footnotetext{
${ }^{107}$ Bundesverfassungsgericht [BVerfG] [Federal Constitutional Court] Oct. 20, 1992, EnTSCHEIDUNGEN DES BundesverfassungSGERICHTS [BVerfGE] 207, 228; Bundesverfassungsgericht [BVerfG] [Federal Constitutional Court] Feb. 5, 2004, ENTSCHEIDUNGEN DES BundesverfassungsGerichts [BVerfGE] 133, 149; Bundesverfassungsgericht [BVerfG] [Federal Constitutional Court] Feb. 15, 2006, ENTSCHEIDUNGEN DES BundESVERFASSUNGSGERICHTS [BVerfGE] 118, 153; Günther Dürig, Der Grundrechtssatz von der Menschenwürde, 81 ARCHIV Des ÖFfentlichen Rechts 117, 127 (1956).

${ }^{108}$ See Thio Li-Ann, Irreducible Plurality, Indivisible Unity: Singapore Relational Constitutionalism and Cultivating Harmony Through Constructing a Constitutional Civil Religion, 20 GERMAN L. J. XX (2019).

${ }^{109}$ See Bosch \& Schittenheim, $\$ 166$ StGB, in SCHÖNKE/SCHRÖDER, STGB (Strafgesetzbuch), note 9 (2019); OLG CELLE, NEUE JURISTISCHE WOCHENSCHRIFT 1275 (1986).

${ }^{110}$ See Bosch \& Schittenheim, supra note 109, note 12 (2019).

${ }^{111}$ OLG CELLE, supra note 109 , at 1275-76.

${ }^{112}$ See generally Thorsten Kingreen \& Ralf Poscher, Grundrechte-StaAtsrecht II paras. 330 et seq. (C.F. Müller, 34th ed. 2018).

${ }^{113}$ See Hesse, supra note 45 , at para. 72.

${ }^{114}$ Bundesverfassungsgericht [BVerfG] [Federal Constitutional Court] Jan. 27, 2015, 138 ENTSCHEIDUNGEN DES BUNDESVERFASSUNGSGERICHTS [BVerfGE] 296, 328 et seq.

${ }^{115}$ BöCKENFÖrde, supra note 64, at 61 et seq.; Niklas Luhmann, Die Gewissensfreiheit und das Gewissen, 90 ARCHIV DES ÖFFENTLICHEN RECHTS 257, 274 (1965).
}

Cite this article: Tan KL, Roßbach M (2019). State Answers to Religious Diversity in Germany and Singapore: History, Philosophy and Strategy. German Law Journal 20, 949-965. https://doi.org/10.1017/glj.2019.79 